\title{
Potential role of Eucalyptus spp. and Acacia spp. allelochemicals in weed management
}

\author{
Paagiotis Kanatas ${ }^{1^{*}}$ \\ ${ }^{1}$ Agricultural Cooperative of Mesolonghi-Nafpaktia, 30200 Mesolonghi, Greece. *Corresponding author (pakanatas@gmail.com).
}

Received: 3 May 2020; Accepted: 28 May 2020; doi:10.4067/S0718-58392020000300452

\begin{abstract}
Eucalyptus spp. and Acacia spp. have been reported as major invaders in several regions and Mediterranean climates. It has been documented that E. globulus and E. camaldulensis can serve as resources of allelochemicals, which can be used as tools of control strategy of noxious weed species infesting the agricultural areas of the Mediterranean region. Additionally, the remarkable allelopathy potential of A. dealbata Link against various weed species has been highlighted in many recent studies. There is also evidence that other species belonging to Acacia spp. can suppress the native vegetation, including weeds, due to their allelopathic potential. However, allelochemical extracts from different plant tissues seem variable in terms of their effects on various species germination and growth parameters. Furthermore, the effectiveness of the allelochemicals in weed management is also a matter of choosing the most appropriate application rate at any case. In the present review, aspects of the potential role of Eucalyptus spp. and Acacia spp. allelochemicals in weed management were discussed. Further research is needed in order to optimize the use of such allelochemicals produced by invasive plants in the Mediterranean region in both organic and sustainable agriculture systems.
\end{abstract}

Key words: Acacia spp., allelopathy, Eucalyptus spp., invasive, weed management.

\section{INTRODUCTION}

Invasive plants have the potential to affect the structure of plant communities globally since they are among the most ubiquitous invasive organisms (Callaway et al., 2004; Arianoutsou et al., 2010). Most invasive plants have been introduced as bioenergy, ornamental or medicinal crops (Williamson, 1996), while some species have been introduced by accident (Newsome and Noble, 1986). The biological impact of plant invasions on flora diversity and ecosystem functions has been highlighted as an objective of extended research (Jackson et al., 2002; Wolfe and Klironomos, 2005; Vila et al., 2010; Hulme et al., 2013).

The pressure on native species is partially attributed not only to direct resource competition but also to the allelopathic potential of plant invaders (Hierro and Callaway, 2003; Levine et al., 2003; Hulme, 2007). Allelopathy is a biological phenomenon through which some plants release organic compounds known as allelochemicals from plant roots, stems, flowers, and leaves tissues to influence growth, survival and reproduction of neighboring plants (Ben Ghnaya et al., 2016). Allelochemicals consist of a variety of organic compounds such as simple polysaccharides, amino acids, organic acids and phenolic compounds (Inderjit and Duke, 2003). Allelopathic compounds have been reported to reduce seed germination, growth and establishment of surrounding plants (Fan et al., 1997; Wang et al., 2014). Although many of the plant invaders are not dominant in their natural habitat, they can become strong competitors of the plant species of the invaded ecosystem and that can be related to their allelochemical potential (Callaway 2000; Orr et al., 2005).

Weed control is mainly dependent on herbicides whose increased use is associated with issues such as evolvement of weed resistance to herbicides, crop injury, soil and water pollution, toxicity patterns to non-target organisms and 
concerns for human health (Li et al., 2003; Meksawat and Pornprom, 2010; Pot et al., 2011; Heap, 2014). Given that as a fact, weed scientists seek for alternative weed management practices less reliant on herbicides (Hiltbrunner et al., 2007; Kanatas et al., 2020). The allelopathic effects of invasive species on growth and development of native species, including noxious weed species, have been reported and set an interesting area of research regarding weed management efforts (Ben Ghnaya et al., 2016). The main objective of the current literature review was to point out the potential role of allelochemicals produced by invasive species in the Mediterranean region on developing more efficient and eco-friendly weed management practices.

\section{ALLELOPATHIC EFFECTS OF EUCALYPTUS SPP. ON WEEDS}

\section{Allelopathic effects of Eucalyptus globulus Labill. on weeds}

Eucalyptus spp. (Myrtaceae) are plant species widely used for the production of wood but they also have ability to suppress the establishment of understory native plants, including noxious weed species, under the dry climatic conditions of the Mediterranean regions (Almeida and Freitas, 2006; Giardina et al., 2007). This is partially attributed to phenolic and volatile compounds contained in the leaf tissues of the plant invaders and act as allelochemicals against the native vegetation (AlNaib and Al-Mousawi, 1976; May and Ash, 1990). The presence of several terpenes which act as allelochemicals such as 1,8-cineol, limonene, $\alpha$ - and $\beta$-pinene has been also reported in Eucalyptus spp. (Muller et al., 1964). The two most widespread species in the world are E. globulus Labill. and E. camaldulensis Dehnh. (Andreu et al., 2009). Eucalyptus globulus has invaded into Mediterranean countries such as Spain, Italy and Greece (Sanz-Elorza et al., 2001; Giardina et al., 2007; Galanos, 2015). The species E. camaldulensis has also been recognized as invader in Spain, Portugal, Greece and Italy (Sanz-Elorza et al., 2001; Almeida and Freitas, 2006; Arianoutsou et al., 2010; Lazzaro et al., 2014).

It has been reported that leachates as derived from E. globulus fresh leaves reduced the resprouting ability of the sedge Cyperus rotundus L. by 57\%-68\% when applied at the concentrations of $20 \%(\mathrm{w} / \mathrm{v})$ and $40 \%(\mathrm{w} / \mathrm{v})$ whereas the corresponding reduction in resprouting of the noxious perennial grass Cynodon dactylon (L.) Pers. ranged between $82 \%$ and $89 \%$ (Babu and Kandasamy, 1997). Rhizomes of $C$. dactylon can lose up to $60 \%$ of their total weight due to the incorporation of E. globulus leaves in the soil at a rate of $100 \mathrm{~g} \mathrm{~kg}^{-1}$ whereas the corresponding reduction of foliage dry weight can reach the level of 64\% (El-Rokiek et al., 2011). In another study, E. globulus essential oils reduced growth of $C$. dactylon by $66 \%$ when applied at $25 \%(\mathrm{v} / \mathrm{v})$ concentration of extract whereas in higher concentrations complete inhibition of germination was noted (Daneshmandi and Azizi, 2009). Regarding annual weeds, Azizi and Fuji (2006) noticed that E. globulus essential oils applied at $0.2 \%$ (v/v) concentration reduced the germination of Amaranthus retroflexus L. by $80 \%$ and the germination of Portulaca oleracea L. by $90 \%$ when applied at $0.5 \%(\mathrm{v} / \mathrm{v})$ concentration as compared to the control treatment. In the study of Rassaeifar et al. (2013), the application of E. globulus essential oil at $5 \mathrm{~nL} \mathrm{~mL}^{-1}(\mathrm{v} / \mathrm{v})$ resulted in 50\% lower germination percentage and approximately $39 \%$ lower radicle length and plant height of Amaranthus blitoides S. Watson as compared to the control treatment. The number of branches produced by Echinochloa colona (L.) Link can be reduced by $59 \%$ if E. globulus dry leaves are mixed within the soil profiles whereas the reduction of total plants' fresh weight has been recorded at 66\% (El-Rokiek et al., 2011). A remarkable question is if E. globulus allelochemicals can surpass the effectiveness of a commonly used soil-active herbicide. The findings of Puig et al. (2013) revealed that incorporating E. globulus leaves as green manure into the soil profile at $2 \%(\mathrm{w} / \mathrm{w})$ concentration results in approximately the same level of control of the perennial weed Convolvulus arvensis L. as compared to the case where $S$-metolachlor was applied at $960 \mathrm{~g}_{\text {ai ha- }}{ }^{-1}$. The same authors demonstrated that E. globulus green manure at $1 \%$ $(\mathrm{w} / \mathrm{w})$ reduced the density of broadleaves by $35 \%$ in comparison to the control treatment whereas the total grass weeds' density was by almost $54 \%$ lower as compared to the value recorded under the control treatment (Puig et al., 2013). In the study of Souto et al. (2001), soil bioassays revealed the allelopathic effects of E. globulus on the growth of Lactuca sativa L., Dactylis glomerata L. and Trifolium repens L. under the soil and climatic conditions of Mediterranean region. As suggested by Puig et al. (2018), green manure by E. globulus could be also exploited due to its allelopathic potential.

\section{Allelopathic effects of Eucalyptus camaldulensis Dehnh. on weeds}

In the greenhouse experiment of Del Moral and Muller (1970) it was noticed that covering the soil of the pans with 4-5 layers of leaves of E. camaldulensis can reduce dry weight of Bromus rigidus Roth, B. hordeaceus L. and Avena fatua L. by 24\%, 
$30 \%$ and $48 \%$, respectively, as compared to the case where the soil was left uncovered. In a more recent study it was noted that applying aqueous leaf extracts of E. camaldulensis at $20 \mathrm{~g} \mathrm{~L}^{-1}$ resulted in $53 \%$ and $67 \%$ lower percentage of seed germination for the perennial species Rhaponticum repens (L.) Hidalgo and Plantago lanceolata L., respectively, as compared to the control treatment (Dadkhah and Asaadi, 2010). Verdeguer et al. (2009) indicated that applying $E$. camaldulensis essential oils at various concentrations results in zero germination percentage for the annual species Amaranthus hybridus L. and P. oleracea. The same researchers did also obtain similar results for the herbicidal effects of the essential oils as derived from two other invasive species Lantana camara L. and Eriocephalus africanus L. on the annual weed species mentioned above (Verdeguer et al., 2009). Foliar water extracts of E. camaldulensis at 10 and $20 \mathrm{~g} \mathrm{~L}^{-1}$ reduced $P$. oleracea seed vigor by $48 \%$ and $66 \%$, respectively, as compared to the control treatment whereas the highest concentration of the two resulted in $66 \%$ lower root and shoot length in comparison to the control treatment (Dadkhah, 2013). The foliar aqueous extracts of E. camaldulenis were also effective against Carthamus oxyacantha $\mathrm{M}$. Bieb. since their application at $150 \mathrm{~g} \mathrm{~L}^{-1}$ resulted in $64 \%$ lower seedling length and $79 \%$ lower germination percentage as compared to the control treatment in the study of Khan et al. (2004). Similar observations were reported from the same authors regarding the herbicidal effects of another invasive species, Prosopis juliflora (Sw.) DC. foliar water extracts on germination percentage and seedling length of A. fatua (Khan et al., 2004).

Regarding the allelochemical potential of another species belonging to Eucalyptus spp., essential oil derived from $E$. citriodora Hook. tissues completely diminished seed germination percentage, seed vigor, radicle length and plummule length of Parthenium hysterophorus L. at any concentration applied in the study of Kohli et al. (1998). Complete control of the same weed species has been recorded $2 \mathrm{wk}$ after treatment with E. citriodora essential oils at 75 and $100 \mu \mathrm{L} \mathrm{mL}^{-1}$ (Singh et al., 2005). Aquaeous extracts as derived from fresh leaves of E. citriodora reduced A. fatua root length by $60 \%$ when applied at $10 \%(\mathrm{v} / \mathrm{v})$ concentration in comparison to the control treatment in the study of El-Rokiek and Eid (2009) and were more efficient than extracts derived from dry leaves.

\section{ALLELOPATHIC EFFECTS OF ACACIA SPP. ON WEEDS}

\section{Allelopathic effects of Acacia dealbata Link on weeds}

The genus Acacia spp. belongs to the botanical family of Mimosaceae and there are over 1300 species of Acacia spp. found throughout the world. Almost 1000 of them have been found in Australia whereas 144 species have been noticed in Africa, up to 89 species in Asia, and over 180 species in North and South America (Lorenzo et al., 2010a). More than 20 Acacia species have been confirmed as invasive at global range including Europe and the Medittarenean region (Lorenzo and Rodríguez-Echeverría, 2015). The study of Lorenzo et al. (2010b) indicated the species A. dealbata Link, A. melanoxylon R.Br., A. longifolia (Andrews) Willd., A. retinodes (Schltdl.), A. saligna (Labill.) H.L. Wendl., A. mearnsii De Wild. and A. pycnantha Benth. as the most dominant invaders in Italy, Portugal and Spain.

Of the species mentioned, A. dealbata, a tree that is widely naturalized in Atlantic and Mediterranean climates, has been indicated as the most frequent invader (Sheppard et al., 2006). The invasion of A. dealbata leaded to the limitation of eight native weed species as reported in the study of Lorenzo et al. (2012) and this outcome was mainly attributed to the allelopathic potential of the invader against the native vegetation. Such findings point out the need to investigate if the allelochemicals of Acacia spp. can be used for weed management purposes. There is evidence that A. dealbata leachates produced during the flowering period can affect germination and growth of understory native plants under the soil and climatic conditions of the Mediterranean region (Carballeira and Reigosa, 1999). Lorenzo et al. (2010b) also noticed that net photosynthesis of weeds belonging to the genus Dicranum spp. were significantly affected by leachates and macerates of $A$. dealbata. The leaves of $A$. dealbata can be incorporated as green manure into the soil and reduce the density of $P$. oleracea by approximately $51 \%$ when applied at the concentration of $1.5 \%(\mathrm{w} / \mathrm{w})$ (Souza-Alonso et al., 2020). Similar observations have been made regarding the effects of A. dealbata allelochemicals on the respiration rates of noxious broadleaf weed species Hedera hibernica G. Kirchn. Bean. Souza-Alonso et al. (2020) also recommended that for a fraction of grass weeds, their density might be reduced by $46 \%$ if green manure from A. dealbata leaves and branches is incorporated into the soil profile at concentration of $3.0 \%(\mathrm{w} / \mathrm{w})$. Acacia spp. had negative allelopathic effects on the growth of L. sativa, D. glomerata, and T. repens (Souto et al., 2001). 
Methyl cinnamate is a compound found in the flowers of A. dealbata and other plants (Khanh et al., 2008) and has shown its herbicidal effects on Lolium rigidum Gaudin with its application reducing guaiacol peroxidase activity up to $57 \%$ and also inhibiting early stem and radicle growth of L. rigidum by $76 \%$ and $87 \%$, respectively (Lorenzo et al., 2020). Methyl cinnamate can also significantly reduce $L$. rigidum seed germination and root length when applied at $640 \mathrm{~nL} \mathrm{~cm}^{-3}$ (Vasilakoglou et al., 2013). Given that L. rigidum is a noxious weed species infesting cereal crops with remarkable ability to evolve multiple herbicide patterns to up to 14 different modes of action, the use of allelochemical extracts from plants pose as an alternative and attractive option for its control (Adler and Chase, 2007; Heap, 2014; Travlos et al., 2018).

\section{Allelopathic effects of other species belonging to Acacia spp. on weeds}

Regarding the allelopathic effects of other invasive species belonging to Acacia spp. on weeds, extended research has been carried out during the last two decades. Acacia melanoxylon is a versatile tree considered as invasive especially relevant in Portugal and Spain (Knapic et al., 2006). There is evidence that the decomposition of A. melanoxylon in the soil environment inhibit germination of understory native plants and the inhibitory effects are even more obvious in the growth of the plants exhibited to the allelochemicals of the invader (González et al., 1995). In addition, the findings of a more recent study have established the possible herbicidal potential of A. melanoxylon allelochemicals since it was revealed that flower aqueous extracts at concentrations of $25 \%$ and $50 \%$ can reduce seed germination of Lolium perenne by $68 \%$ and $96 \%$, respectively (Hussain et al., 2011). The same authors demonstrated that phyllode water extracts of $A$. melanoxylon at the concentration of $100 \%$ can increase the number of ungerminated seeds by $80 \%$ (Hussain et al., 2011). Regarding the herbicidal potential of other species, it was shown that radicle length of perennial grass weed species Eragrostis curvula (Schrad.) Nees was by $44 \%$ and $74 \%$ reduced when treated with 10 and $20 \mathrm{~g} \mathrm{~L}^{-1}$ of A. mearnsii aqueous leaves extracts as compared to the control treatment in the study of Fatunbi et al. (2009).

Furthermore, there is evidence that $A$. saligna flower methanol extracts reduce Hordeum murinum L. germination by $56 \%-87 \%$ when applied at 5 and $10 \mathrm{~g} \mathrm{~L}^{-1}$ as compared to control treatments whereas the corresponding effect of methanol leaf extracts on this monocotyledonous species' seed germination can reach 75\% (Abd El Gawad and El-Amier, 2015). It was also reported that A. mearnsii root water extracts can reduce radicle length of E. curvula up to $77 \%$ when applied at $40 \mathrm{~g} \mathrm{~L}^{-1}$ (Fatunbi et al., 2009). For the case of A. longifolia, there is evidence about its herbicidal effects on weeds since its leaves can be incorporated as green manure into the soil profile and reduce total weed density by nearly $20 \%$ when applied at a concentration of 3\% (w/w) (Souza-Alonso et al., 2020). Other recent findings also indicated that the presence of A. saligna under the field conditions of Nile Delta Coast of Egypt can reduce the density of Bromus diandrus, Rumex pictus and Aegilops bicornis while aqueous flower and leaf extracts have inhibitory effects on shoot and root lengths of $H$. murinum (Abd El Gawad and El-Amier, 2015). In Italy, the gradual disappearance of Bromus madritensis, Hypochaeris glabra, Senecio lividus and Galium divaricatum was attributed to A. pycantha invasion whereas other scientists reported that aqueous extracts as derived from A. retinodes flowers can reduce the germination of the broadleaf weed species Carrichtera аппиа more than 30\% if applied at 100\% concentration (Dana and Domingo, 2006; Lazzaro et al., 2015).

Nevertheless, it has to be noted that despite the proven phytotoxicity in vitro, recent work casts some doubt on the allelopathic capacity under natural conditions. For instance, Lorenzo et al. (2016) revealed that the bioactivity of tested compounds was not the same under different conditions and methodologies. Yannelli et al. (2020) suggested that chemically-induced signals may facilitate Acacia spp. establishment, regardless of whether they had overlapping native ranges and consequently it is not valid per se that the release of allelopathic compounds by alien species inhibits the growth of native plants.

\section{CONCLUSIONS}

This review was focused on the potential utility of Eucalyptus spp. and Acacia spp. allelochemicals on weed management. Species of both genera have been reported as major invaders in Mediterranean and other regions. It is well established that E. globulus and E. camaldulensis can serve as a valuable resource of allelochemicals which can be used for the control of noxious weed species infesting the agricultural areas of the Mediterranean region. The remarkable allelopathic potential of A. dealbata against various weed species has been highlighted in many recent studies, even if the bioactivity is not the same under the same conditions and methodologies. There is also evidence that other species belonging to Acacia spp. 
can suppress the native vegetation, including weeds, due their allelopathic potential. However, allelochemical extracts from different plant tissues seem can be within a wide range in terms of their effects on various species germination and growth parameters. Furthermore, the effectiveness of the allelochemicals in weed management is also a matter of choosing the most appropriate application rate at any case. Another parameter that needs to be investigated is which are the allelochemicals most related to the control of each weed species. Further research is needed in order to optimize the use of such allelochemicals produced by invasive plants in the Mediterranean region in terms of weed management in both organic and sustainable agriculture systems.

\section{REFERENCES}

Abd El Gawad, A.M., and El-Amier, Y.A. 2015. Allelopathy and potential impact of invasive Acacia saligna (Labill.) Wendl. on plant diversity in the Nile Delta Coast of Egypt. International Journal of Environmental Research 9:923-932.

Adler, M.J., and Chase, C.A. 2007. Comparison of the allelopathic potential of leguminous summer potential crops: cowpea, sunn hemp and velvet bean. HortScience 42:289-293.

Almeida, J.D., and Freitas, H. 2006. Exotic flora of continental Portugal - a reassesment. Botanica Complutensis 30:117-130.

Al-Naib,F.A.G., and Al-Mousawi, A.H. 1976. Allelopathic effects of Eucalyptus microtheca. Identification and characterization on the phenolic compounds in Eucalyptus microtheca. Journal of University of Kuwait (Science) 3:83-87.

Andreu, J., Vilá, M., and Hulme, P.E. 2009. An assessment of stakeholder perceptions and management of noxious alien plants in Spain. Environmental Management 43:1244-1255.

Arianoutsou, M., Bazos, I., Delipetrou, P., and Kokkoris, Y. 2010. The alien flora of Greece: taxonomy, life traits and habitat preferences. Biological Invasions 12:3525-3549.

Azizi, M., and Fuji, Y. 2006. Allelopathic effect of some medicinal plant substances on seed germination of Amaranthus retroflexus and Portulaca oleraceae. Acta Horticulturae 699:61-68.

Babu, R.C., and Kandasamy, O.S. 1997. Allelopathic effect of Eucalyptus globulus Labill. on Cyperus rotundus L. and Cynodon dactylon L. Pers. Journal of Agronomy and Crop Science 179:123-126.

Ben Ghnaya, A., Hamrouni, L., Amri, I., Ahoues, H., Hanana, M., and Romane, A. 2016. Study of allelopathic effects of Eucalyptus erythrocorys L. crude extracts against germination and seedling growth of weeds and wheat. Natural Product Research 30:2058-2064.

Callaway, R.M. 2000. Invasive plants versus their new and old neighbors: A mechanism for exotic invasion. Science 290:521-523.

Callaway, R.M., Thelen, G.C., Rodriguez, A., and Holben, W.E. 2004. Soil biota and exotic plant invasion. Nature 427:731-733.

Carballeira, A., and Reigosa, M.J. 1999. Effects of natural leachates of Acacia dealbata Link in Galicia (NW Spain). Botanical Bulletin of Academia Sinica 40:87-92.

Dadkhah, A. 2013. Allelopathic effect of sugar beet (Beta vulgaris) and eucalyptus (Eucalyptus camaldulensis) on seed germination and growth of Portulaca oleracea. Russian Agricultural Sciences 39:117-123.

Dadkhah, A., and Asaadi, A.M. 2010. Allelopathic effects of Eucalyptus camaldulensis on seed germination and growth seedlings of Acroptilon repens, Plantago lanceolata and Portulaca oleracea. Research Journal of Biological Sciences 5:430-434.

Dana, E.D., and Domingo, F. 2006. Inhibitory effects of aqueous extract of Acacia retinodes Schltdl., Euphorbia serpens L., and Nicotiana glauca Graham on weeds and crops. Allelopathy Journal 18:323-330.

Daneshmandi, M.S., and Azizi, M.A.J.I.D. 2009. Allelopathic effect of Eucalyptus globulus Labill. on bermuda grass (Cynodon dactylon (L.) Pers.) germination and rhizome growth. Iranian Journal of Medicinal and Aromatic Plants 25:333-346.

Del Moral, R., and Muller, C.H. 1970. The allelopathic effects of Eucalyptus camaldulensis. American Midland Naturalist 83:254-282.

El-Rokiek, K.G., and Eid, R.A. 2009. Allelopathic effects of Eucalyptus citriodora on amaryllis and associated grassy weed. Planta Daninha 27:887-899.

El-Rokiek, K.G., Messiha, N.K., El-Masry, R.R., El-Din, S.S., and Samia, A. 2011. Evaluating the leaf residues of Eucalyptus globulus and Mangifera indica on growth of Cynodon dactylon and Echinochloa colonum. Journal of Applied Sciences Research 7:1793-1799.

Fan, T.W.M., Lane, A.M, Crowley, D., and Higashi, R.M. 1997. Comprehensive analysis of organic ligands in whole root exudate using nuclear magnetic resonance and gas chromatography-mass spectrometry. Analytical Biochemistry 251:57-68

Fatunbi, A.O., Dube, S., Yakubu, M.T., and Tshabalala, T. 2009. Allelopathic potential of Acacia mearnsii De Wild. World Applied Sciences Journal 7:1488-1493.

Galanos, C.J. 2015. The alien flora of terrestrial and marine ecosystems of Rodos island (SE Aegean), Greece. Willdenowia 45:261-278.

Giardina, G., Raimondo, F.M., and Spadaro, V. 2007. A catalogue of plants growing in Sicily. Bocconea 20:5-582.

González, L., Souto, X.C., and Reigosa, M.J. 1995. Allelopathic effects of Acacia melanoxylon R.Br. phyllodes during their decomposition. Forest Ecology and Management 77:53-63. 
Heap, I. 2014. Herbicide resistant weeds. p. 281-301. In Pimentel, D., and Peshin, R. (eds.) Integrated pest management. Springer, Dordrecht, Netherlands.

Hierro, J.L., and Callaway, R.M. 2003. Allelopathy and exotic plant invasion. Plant and Soil 256:29-39.

Hiltbrunner, J., Liedgens, M., Bloch, L., Stamp, P., and Streit, B. 2007. Legume cover crops as living mulches for winter wheat: components of biomass and the control of weeds. European Journal of Agronomy 26:21-29.

Hulme, P.E. 2007. Biological invasions in Europe: drivers, pressures, states, impacts and responses. p. 56-80. In Hester, R., and Harrison, R.M. (eds.) Biodiversity under threat. Cambridge University Press, Cambridge, UK.

Hulme, P.E., Pysek, P., Jarosík, V., Pergl, J., Schaffner, U., and Vilá, M. 2013. Bias and error in understanding plant invasion impacts. Trends in Ecology \& Evolution 28:212-218.

Hussain, M.I., Gonzalez, L., and Reigosa, M.J. 2011. Allelopathic potential of Acacia melanoxylon on the germination and root growth of native species. Weed Biology and Management 11:18-28.

Inderjit, K.L., and Duke, S.O. 2003. Ecophysiological aspects of allelopathy. Planta 217:529-539.

Jackson, R.B., Banner, J.L., Jobbágy, E.G., Pockman, W.T., and Wall, D.H. 2002. Ecosystem carbon loss with woody plant invasion of grasslands. Nature 418:623-626.

Kanatas, P.J., Travlos, I.S., Gazoulis, J., Antonopoulos, N., Tsekoura, A., Tataridas, A., et al. 2020. The combined effects of false seedbed technique, post-emergence chemical control and cultivar on weed management and yield of barley in Greece. Phytoparasitica 48:131-143.

Khan, M.A., Marwat, K.B., and Hassan, G. 2004. Allelopathic potential of some multipurpose trees species (MPTS) on the wheat and some of its associate's weeds. International Journal of Biology and Biotechnology 1:275-278.

Khanh, T.D., Cong, L.C., Xuan, T.D., Lee, S.J., Kong, D.S., and Chung, I.M. 2008. Weed-suppressing potential of dodder (Cuscuta hygrophilae) and its phytotoxic constituents. Weed Science 56:119-127.

Knapic, S., Tavares, F., and Pereira, H. 2006. Heartwood and sapwood variation in Acacia melanoxylon R. Br. trees in Portugal. Forestry 79:371-380.

Kohli, R.K., Batish, D.R., and Singh, H.P. 1998. Eucalypt oils for the control of Parthenium (Parthenium hysterophorus L.) Crop Protection 17:119-122.

Lazzaro, L., Ferretti, G., Giuliani, C., and Foggi, B. 2014. A checklist of the alien flora of the Tuscan Archipelago (Italy). Webbia 69:157-176.

Lazzaro, L., Giuliani, C., Benesperi, R., Calamassi, R., and Foggi, B. 2015. Plant species loss and community nestedness after leguminous tree Acacia pycnantha invasion in a Mediterranean ecosystem. Folia Geobotanica 50:229-238.

Levine, J.M., Vilá, M., D’Antonio, C.M., Dukes, J.S., Grigulis, K., and Lavorel, S. 2003. Mechanisms underlying the impacts of exotic plant invasions. Proceedings of Royal Society of London. Series B: Biological Sciences 270:775-781.

Li, Y., Sun, Z., Zhuang, X., Xu, L., Chen S., and Li, M. 2003. Research progress on microbial herbicides. Crop Protection 22:247-252.

Lorenzo, P., González, L., and Reigosa, M.J. 2010a. The genus Acacia as invader: the characteristic case of Acacia dealbata Link in Europe. Annals of Forest Science 67:101.

Lorenzo, P., Palomera-Pérez, A., Reigosa, M.J., and González, L. 2010b. Allelopathic interference of invasive Acacia dealbata Link on the physiological parameters of native understory species. Plant Ecology 212:403-412.

Lorenzo, P., Pazos-Malvido, E., Rubido-Bará, M., Reigosa, M.J., and González, L. 2012. Invasion by the leguminous tree Acacia dealbata (Mimosaceae) reduces the native understorey plant species in different communities. Australian Journal of Botany 60:669-675.

Lorenzo, P., Reboredo-Durán, J., Muñoz, L., Freitas, H., and González, L. 2020. Herbicidal properties of the commercial formulation of methyl cinnamate, a natural compound in the invasive silver wattle (Acacia dealbata). Weed Science 68:69-78.

Lorenzo, P., Reboredo-Durán, J., Muñoz, L., González, L., Freitas, H., and Rodriguez-Echeverria, S. 2016. Inconsistency in the detection of phytotoxic effects: a test with Acacia dealbata extracts using two different methods. Phytochemistry Letters 15:190-198.

Lorenzo, P., and Rodríguez-Echeverría, S. 2015 Soil changes mediated by invasive Australian acacias. Ecosistemas 24:59-66.

May, F.E., and Ash, J.E. 1990. An assessment of the allelopathic potential of Eucalyptus. Australian Journal of Botany 38:245-254.

Meksawat, S., and Pornprom, T. 2010. Allelopathic effect of itchgrass (Rottboellia cochinchinensis) on seed germination and plant growth. Weed Biology and Management 10:16-24.

Muller, C.H., Muller, W.H., and Haines, B.L. 1964. Volatile growth inhibitors produced by aromatic shrubs. Science 143:471-473.

Newsome, A.E., and Noble, I.R. 1986. Ecological and physiological characters of invading species. p. 1-20. In Groves, R.H., and Burdon, J.J. (eds.) Ecology of biological invasions. Cambridge University Press, New York, USA.

Orr, S.P., Rudgers, J.A., and Clay, K. 2005. Invasive plants can inhibit native tree seedlings: testing potential allelopathic mechanisms. Plant Ecology 181:153-165.

Pot, V., Benoit, P., Le Menn, M., Eklo, O.M., Sveistrup, T., and Kvaerner, J. 2011. Metribuzin transport in undisturbed soil cores under controlled water potential conditions: experiments and modeling to evaluate the risk of leaching in a sandy loam soil profile. Pest Management Science 67:397-407. 
Puig, C.G., Álvarez-Iglesias, L., Reigosa, M.J., and Pedrol, N. 2013. Eucalyptus globulus leaves incorporated as green manure for weed control in maize. Weed Science 61:154-161.

Puig, C.G., Goncalves, R.F., Valentao, P., Andrade, P.B., Reigosa, M.J., and Pedrol, N. 2018. The consistency between phytotoxic effects and the dynamics of allelochemicals release from Eucalyptus globulus leaves used as bioherbicide green manure. Journal of Chemical Ecology 44:658-670.

Rassaeifar, M., Hosseini, N., Asl, N.H.H., Zandi, P., and Aghdam, A.M. 2013. Allelopathic effect of Eucalyptus globulus' essential oil on seed germination and seedling establishment of Amaranthus blitoides and Cynodon dactylon. Trakia Journal of Sciences 11:73-81.

Sanz-Elorza, M., Dana, E., y Sobrino, E. 2001. Listado de plantas alóctonas invasoras reales y potenciales en España. Lazaroa 22:121-131.

Sheppard, A.W., Shaw, R.H., and Sforza, R. 2006. Top 20 environmental weeds for classical biological control in Europe: a review of opportunities, regulations and other barriers to adoption. Weed Research 46:93-117.

Singh, H.P., Batish, D.R., Setia, N., and Kohli, R.K. 2005. Herbicidal activity of volatile oils from Eucalyptus citriodora against Parthenium hysterophorus. Annals of Applied Biology 146:89-94.

Souto, X.C., Bolaño, J.C., González, L., and Reigosa, M.J. 2001. Allelopathic effects of tree species on some soil microbial populations and herbaceous plants. Biologia Plantarum 44:269-275.

Souza-Alonso, P., Puig, C.G., Pedrol, N., Freitas, H., Rodríguez-Echeverría S., and Lorenzo, P. 2020. Exploring the use of residues from the invasive Acacia sp. for weed control. Renewable Agriculture and Food Systems 35:26-37.

Travlos, I., Roussis, I., Roditis, C., Semini, C., Rouvali, L., Stasinopoulou, P., et al. 2018. Allelopathic potential of velvet bean against rigid ryegrass. Notulae Botanicae Horti Agrobotanici Cluj-Napoca 46:173-176.

Vasilakoglou, I., Dhima, K., Paschalidis, K., and Ritzoulis, C. 2013. Herbicidal potential on Lolium rigidum of nineteen major essential oil components and their synergy. Journal of Essential Oil Research 25:1-10.

Verdeguer, M., Blázquez, M.A., and Boira, H. 2009. Phytotoxic effects of Lantana camara, Eucalyptus camaldulensis and Eriocephalus africanus essential oils in weeds of Mediterranean summer crops. Biochemical Systematics and Ecology 37:362-369.

Vila, M., Basnou, C., Pysek, P., Josefsson, M., Genovesi, P., Gollasch, S., et al. 2010. How well do we understand the impacts of alien species on ecosystem services? A pan-European, cross-taxa assessment. Frontiers in Ecology and the Environment 8:135-144.

Wang, Q., Xu, Z., Hu, T., Rehman, H., Chen, H., Li, Z., et al. 2014. Allelopathic activity and chemical constituents of walnut (Juglans regia) leaf litter in walnut-winter vegetable agroforestry system. Natural Product Research 28:2017-2020.

Williamson, M. 1996. Biological invasions. Chapman \& Hall, London, UK.

Wolfe, B.E., and Klironomos, J.N. 2005. Breaking new ground: soil communities and exotic plant invasion. Bioscience 55:477-487.

Yannelli, F.A., Novoa, A., Lorenzo, P., Rodríguez, J., and Le Roux, J.J. 2020. No evidence for novel weapons: biochemical recognition modulates early ontogenetic processes in native species and invasive acacias. Biological Invasions 22:549-562. 